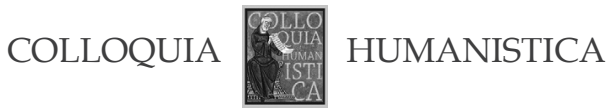

\author{
Péter Krasztev \\ Department of Social Communication \\ Budapest Business School \\ Budapest \\ krasztev@gmail.com
}

\title{
In the Twilight of Ideologies: Power and Esotericism in Soviet State Socialism
}

\begin{abstract}
At the turn of the 19th and 20th centuries, esoteric/occult ideas and movements played an important part in the intellectual, scientific and artistic life of Russia. Occultism lived in symbiosis for some time with virtually every 19th-century ideology, and, to a certain degree, it managed to convert this strange ability into the ideological environment of state socialism as well - a system that was officially hostile towards occultism. However, the relationship between state power, based on "dialectic materialism", and the various forms of occult ideas that survived in that era was not always clear: it kept changing with time, and depended on the influence of those ideas on society. In this paper I will propose some frameworks for the interpretation of the bizarre dynamics between esotericism and Soviet state power, and argue that the reactions of state power to the various manifestations of esoteric ideas - from (quasi-) scientific to community-building and individualistic manifestations - require different interpretative approaches.
\end{abstract}

Keywords: Soviet science, esoteric movements, parapsychology, occultism, non-standard physical phenomena, resistance, secret service.

This is an Open Access article distributed under the terms of the Creative Commons Attribution 3.0 PL License (creativecommons.org/licenses/by/3.0/pl/), which permits redistribution, commercial and non-commercial, provided that the article is properly cited. () The Author(s), 2019.

Publisher: Institute of Slavic Studies, Polish Academy of Sciences

Editor-in-chief: Jolanta Sujecka

Conception and academic editing of this issue: Katarzyna Roman-Rawska, Tomasz Rawski 


\section{Introduction}

Tn December 1987, a strange trial took place in Moscow. Ninel Kulagina,

a woman with psychic powers who had been well known in the Soviet Union for decades, sued the official gazette of the Ministry of Justice for defamation of character ${ }^{1}$. In January the court decided that calling Kulagina a "charlatan" qualified as libel, and obliged the paper to correct their previous statements. The decision of the court was based on the testimony of a number of academics, medical doctors and physicists who had been trying to make sense of Kulagina's powers for twenty years and who all testified to the soundness of her claim. The experts unanimously said that there was no magic or mysticism involved in their research - they had merely conducted a scientific study of a number of unusual natural phenomena, including telekinesis (the ability to move objects without touching them) and bioenergy (Perevozchikov, 1988). ${ }^{2}$ This was the time of the triumph of perestroika, glasnost and democracy, at least in the eyes of those who considered themselves progressive: a simple citizen could win a lawsuit against an institution once deemed omnipotent. Therefore, other aspects of the trial were not discussed in public - not even the fact that, as became evident in the course of the trial, in the land of dialectic materialism and scientific socialism, substantial resources had been allocated to the research of realms in which the laws of physics do not apply, even before the dictatorship became milder, without officially informing the public of the results. The reaction to the Kulagina affair shows, on the one hand, that the non-official publicity of state socialism took the interest of the state in such matters for granted, and suggests, on the other, that this particular case was merely the tip of the iceberg, a manifestation of an internal struggle that had been going on under the surface for some time.

The relationship between state socialism and esotericism in successive periods of the former was at least as dynamic and diverse as the relationship

\footnotetext{
Quoted in Perevozchikov, 1988.

2 In 1988, Tekhnika Molodëzhi, a widely read scientific journal for Soviet youth, published the complete minutes of the Kulagina trial in three consecutive issues. This unique document of the era would merit a thorough analysis in itself as, although what seemed to be at stake in the trial was personality rights, in fact, on a deeper level of their narratives, both the jurists and the scientists who acted as witnesses in the trial faced the question whether there existed an unofficial reality parallel to the "Soviet reality" which was about to perish at the time the trial took place. The legal representative of Kulagina consistently argued that it was not only in terms of human rights that perestroika had altered the ideological framework of the Soviet state: the scientific works that were used to qualify his client as a charlatan were ideological products, and as such, they had lost their validity. Absurdly enough, parapsychology came out as the winner of the argument, as it represented a new "alternative reality". It was an era of stagnation not only in the political and economic sense: adsons as well: with the 'efore, all of whomways froms
} 
of this bygone historical formation to other social phenomena - religion, ethnicity, tradition, sexuality, etc. The difference was perhaps that resolutions concerning debates about non-standard physical phenomena, beliefs, and behaviour related to such phenomena hardly made it into the public sphere, therefore these processes can only be assessed indirectly and in a rather speculative manner. ${ }^{3}$ The majority of literature on this controversial topic basically reiterates the facts known from the "second public sphere" of the time, and they mainly comment - whether explicitly or implicitly - on the cognitive dissonance that although the Soviet state and its satellite states were supposedly based on solid dialectic materialistic principles (whatever that means), they in fact had a keen interest in paranormal phenomena. In most of the cases, they were motivated by the curiosity to find out how hitherto unknown forces of nature could be used to rout out the enemy, both external (the "imperialists") and internal ("deviant" people), and they were ready to devote financial resources to this aim. A number of works on this topic focus on hearsay about the superstitiousness of party leaders after Stalin. These leaders exploited occult phenomena and took them seriously, while this possibility was denied to their subjects. In the hospital of the Kremlin, bioenergy experts were employed, especially to cure Brezhnev (I personally interviewed one of them, Ruslan Magomedov, in 1996) ${ }^{4}$, some leaders of the state consulted oracles, like Bulgarian party secretary Todor Zhivkov who regularly consulted Vanga, a blind soothsayer, before making political decisions, or Gustav Husák, secretary general of the Communist Party of Czechoslovakia, whose government financed the development of "psychotronic generators".

\footnotetext{
3 There were some academic debates related to parapsychology, like the one initiated by leading Soviet psychologist Alexei Leont'ev (in co-authorship) in 1973 (Leont'ev, Lomov, Zinchenko, \& Luriia, 1973). However, their critical attitude towards the "psy-phenomenon" was more pragmatic than ideological or conceptual (i.e. they claimed that practitioners lacked competence and their results were not convincing). Cf. the Soviet public discourse on Leont'ev's article and parapsychology in Menzel, 2016.

4 Parts of the interview were broadcast in a documentary programme of Hungarian National TV (14 October 1996, 16:30 Tranzit. Közép- Európai Magazin - Tranzit, Central European Broadcast)

5 The literature available on these topics is virtually impossible to review. Let me just enumerate a few examples in order to show the type and reliability of the sources: some of these are memoirs of party and state functionaries, e.g. Baibakov, N. K. Sorok let v pravitelstve (Baúbakov, 2011); or Chazov, E. Khorovod smerter. Brezhnev, Andropov, Chernenko (Chazov, 2014); others are articles without references, e.g. Alexander, 1980; Antonov, 2015; Greig, 2016; Maire \& LaMothe, 2014; Moiseeva, 2018. One of the most recent mystifications in this respect is PSI-vorny: Zapad i Vostok. Istoriia voennogo primeneniia èstrasensoriki (Rubel', 2013); Engl. ESP WARS: East and West: An Account of the Military Use of Psychic Espionage as Narrated by the Key Russian and American Players, by Edwin C. May and Victor Rubel (May \& Rubel, 2014). (See a sober critical analysis here: Politdrug, 2015)
} 
In my paper I attempt to outline some possible directions for further research, as well as to reflect on some papers that have previously examined these phenomena, the methodology and approach of which could provide guidelines for the interpretation of this theoretically and historically extremely diverse topic which affected the fate of countless individuals. If one examines the relationship between state socialism and esotericism in the modern era from the point of view of our time, it seems quite clear that although both phenomena are rooted in the Enlightenment, the ideologues of the Soviet state were not aware of this. In other words, the cyclically changing relation of Soviet state power to phenomena that cannot be explained by science was by no means due to complex interactions between the political ideology and the specific Russian/Soviet academic narrative: these reactions were guided by random, often pragmatic considerations, and determined by personal character. The social, psychological, historical, scientific and political dimensions of esotericism in state socialism are so intricate that it would be next to impossible to find a uniformly valid interpretative framework which would include all the aspects. In what follows, I will present three reactions of the state socialist system for the control of esotericism - mainly in Soviet Russia - which only partly follows the chronological order and is based rather on particular manifestations of this version of esotericism, and their socio-political impacts. This may sound somewhat vague, but this is due less to methodological uncertainty and more to the fact that an issue which involves irrational elements by virtue of its character and is therefore hard to formulate in words, necessarily requires a lot of paraphrase.

1. Controlled esotericism: parapsychology is subsumed under the natural sciences and the secret services. This involves an ambivalent but by no means prohibitive approach on the part of official, materialist state science to non-conventional research.

2. Esotericism as a threat to society: movements, lodges and groups established at the turn of the 19th and 20th centuries are eliminated, their members are physically annihilated.

3. Corrective control by the state power in the period of so-called thaw, then so-called stagnation: the state power considers esotericism as an ideological deviance of individuals or lifestyle communities, keeps it under surveillance, and in extreme cases separates such individuals from society based on supposed mental health issues.

There are examples illustrating all three approaches in the Soviet Union, a country which had an approach to science different to the Western one (as I will explain later) and a doctrinaire view of ideology, but this division is valid (with some qualifications) for the majority of societies under Soviet control. 
For practical reasons, I will refrain from an intellectual historical analysis of the concepts of occult, mystical and esoteric (often used as synonyms), and I will use these words in the everyday sense to denote phenomena which are hidden, or only understood by the initiated, and I will include "paranormal phenomena" as well. ${ }^{6}$ Instead, I will focus on the attitude of society to unexplainable, mysterious phenomena that lie outside the scientific paradigm.

\section{Natural Science: Esoterica under Control}

In his book Sapiens: A Brief History of Humankind, Yuval N. Harari calls liberalism, communism, capitalism, nationalism and Nazism "natural-law religions" of the modern era. A few pages before that, he claims that every monotheistic and ideology-based religion is necessarily syncretic (Harari, 2014, pp. 200-202). How well occultism-related parapsychology fits into this syncretic world is well illustrated by a CIA report from 1977 which claims that the main difference between American and Soviet research was that while the Americans were busy proving the existence of paranormal phenomena to their would-be sponsors, the Russians were already working on applying such phenomena in practice (Hamilton, 1977). In other words, the scientists of the Soviet state - with relatively few exceptions ${ }^{7}$ - were not preoccupied with verifying whether clairvoyance, telekinesis, telepathy, mind-reading, aura or healing bioenergy existed, but with ways of putting these phenomena into practice. This is self-confident pragmatism indeed but what is the source of such self-assurance?

According to Bernice Glatzer Rosenthal (1997), the reasons go back to the past. In her book The Occult in Russian and Soviet Culture (1997), she convincingly argues that virtually every important actor of Russian culture before 1917 - from Diaghilev to Berdiaev, Khlebnikov and Malevich - had contacts with occult groups or at least the influence of such groups can be traced in their works. One would be hard put to refute her claim that in the years preceding the Bolshevik takeover, the whole of Russian culture and

\footnotetext{
6 The terms mystical, esoteric, spiritual, occult, paranormal as well as their interconnectedness have always been difficult to define. The controversy and the specific nuances of the usage of terminology in the Western and the Russian academic literature is described in detail in the Introduction to the volume The New Age of Russia: Occult and Esoteric Dimensions (Menzel, 2012a, pp. 18-23).

7 See Menzel, 2016 about the debate around Leont'ev's article. However, in the article on Parapsychology in the Great Soviet Encyclopaedia, published between 1969 and 1978 and strictly reflecting the official Soviet ideological standpoint of the time, two of the authors of the incriminated article (Leont'ev and Zinchenko) are still hesitant to provide a straightforward statement about the pseudo-scientific character of parapsychology and related phenomena ("Parapsikhologiia: Znachenie slova 'Parapsikhologiia' v Bol'shoĭ Sovetskoı̆ Ėntsiklopedii”, n.d.)
} 
public mind was pervaded with occult ideas, but it is hard to tell whether these were coherent thought patterns and artistic motifs or rather the direct influence of Gurdjieff, Ouspensky, Steiner and other contemporary metaphysical thinkers. Although it is true that these motifs still appear in Russian art today, the ideological commitment of the artists is by no means as evident as Glatzer Rosenthal seems to suggest - using a motif in a work of art does not necessarily mean that the artist identifies with its ideological content. Besides, as I mentioned above, occultism was rather protean in terms of ideological content, and it readily adapted itself to local circumstances, often assuming national features, like in the case of the painter and occultist Nikolai Rerikh. ${ }^{8}$ Also, it typically flourished at times and in places where chaos reigned: where old rules had lost their validity and new rules were not yet strong enough - in Durkheim's term, where anomy was rampant.

The early period of Russian spiritualism is well documented ${ }^{9}$, but one must keep in mind that this pre-history began in 1875 when the classical scientific paradigm still resisted the pressure of occultism in Russia. In that year, a committee for medium research was set up at the university of Saint Petersburg, headed by none other than Mendeleev. Contradicting several members of the committee, the chemist declared that spiritism was a hoax, yet at the end of his summary lecture he elegantly added that science must always be open-minded, and, rather than silencing new ideas, it must be ready to enter into debate with them (Mendeleev, 1876, p. 381). This gesture was judged by the bigoted Orthodox public - including Dostoevskii - as tantamount to dancing with the devil (Dostoevskiĭ, 1972-1990, pp. 36-37). However, Russian science proved to be susceptible to such leniency: it was merely a matter of a decade before, in 1885, Bekhterev established the first experimental laboratory specializing in telepathy (among other things), and in the next few decades he developed a psycho-physiological theory based on "world energy" which is manifested in every living being - a theory that became one of the main tenets of Russian-Soviet psychology (Shingarov, 1994, pp. 19-20). Although in his paper written in 1917 he declared that telepathy, at least in the manifestations that had been researched until then, was mere legerdemain, he made the same concessive gesture as Mendeleev had a few decades before: he denied that science could be divided into an "official" and an "unofficial" realm, and he did not categorically reject the further examination of telepathic phenomena (Bekhterev, 1994, pp.321-323).

Later on, every new era tried to give a theoretical explanation to the unexplainable: four years after Bekhterev's laboratory had been established, Julian Ochorowicz, a professor of philosophy, psychology and physiology,

For the origin and composition of Rerikh's eclectic metaphysical ideas, see Osterrieder, 2012.

For details see Vinitsky, 2008. 
held a lecture on the electro-induction theory of telepathy. After that, every period that followed had its own theory explaining telepathy in the Soviet Union: the magnetic wave theory was born (Kazhinskii, 1923), and a few decades later, it was developed into the radio wave theory (1977-1980 Gulaev and Kobzarev; the former was a crown witness in the Kulagina trial described in the introductory paragraph of this paper), accepted as authoritative in Soviet scientific circles. In Western Europe, Freud pronounced his ultimate verdict on telepathy virtually at the same time as Kazhinskiu pronounced his own in his lecture entitled "Psycho-analysis and Telepathy", in which he relates telepathy to occultism, to be studied as a religious rather than a scientific phenomenon. With admirable discernment, Freud warns that the reason occultism is so virulent is precisely that it finds common ground with almost every new scientific theory, which gives occultism new ammunition for survival (Freud, 1921/1941, pp. 27-44). For the Soviet Union, this proved a self-fulfilling prophecy: protean occultism, especially those of its elements which could be used to influence the masses, tempted even hard-core Marxist and materialist scientists. ${ }^{10}$ It would be going too far to claim that that was the point where Soviet-Russian scientific thinking started to veer away from Western science, but their respective attitudes towards telepathy clearly demonstrate the essential differences between their outlooks.

In the background of all this, one can recognize the philosophical basis of Russian natural science, influenced by the ideas of Nikolai Fëdorov and Vladimir Solovëv, who were both strongly influenced by occult principles. To that, the scientific thinking of "Russian cosmism" was added, founded by Tsiolkovskii (the father of Russian space research), Vladimir Vernadskii (who developed the concept of the noosphere, i.e. the "sphere of thought" that replaced the biosphere), and Chizhevskiü (who researched cosmic radiation).

10 If we accept that "alternative" scientific works were banned in the Soviet Union as a result of the centralized academic system and censorship in publishing, we must consider the point of view of Kazhinskiľ, put forward in his book entitled Biological Radio Communication (1963), as "official" or mainstream. The central metaphor or interpretative framework of that book is the wonder of the age, electronics and radio technology, through which the author (and his contemporaries) try to explain the phenomenon of thought transference. He considers the human central nervous system a sort of "radio transmitter" the organs of which transmit signals that can be picked up by others, with the "receiver" having his or her own parts/organs to receive and decode the message. It needs noting that in his introduction, Kazhinskiĭ refers to Mendeleev's "concessive" gesture quoted above and Bekhterev's research (and to Lenin, of course, but that was obligatory at the time). He also recalls Tsiolkovskiı̌s encouragement and support. Kazhinskiǐs argument is based on the idea that in the beginning of our history, human beings were probably able to communicate through telepathy, but they lost that ability in the course of evolution, and what we can experience and research now is only remnants of it. He puts the temporary lack of substantial results mostly down to the imperfection of our instruments (Kazhinskiü, 1963). 
According to their holistic theoretical "interpretative framework", the human intellect must assume a leading role in the universe, and take part actively and responsibly in its evolutionary processes. ${ }^{11}$ According to this theory, higher, "planetary" consciousness can be achieved if humanity is transformed into "intelligent living material", and subjects itself to universal morality.

These theoreticians essentially preached the birth of a "new man", a mystical transformation, and the elevation of the Nietzschean Übermensch. Tsiolkovski1̌, for example, who discussed the idea of a spaceship at the beginning of the 20th century, was confident that "The existence of telepathic phenomena is beyond doubt. There is not only a huge amount of factual material supporting their existence, but almost every person who has a family is keen to relate their experience of telepathic phenomena". ${ }^{12}$ It is with this sentence by Tsiolkovskir that Leonid Vasilev, the neurophysiologist whose research on stress preceded Western science by decades, starts his book on telepathy, written in the 1930s but not published until 1962. In this book, Vasilev argues with the interpretation of telepathy by spiritists and occultists, and defines the soul (the mind) as a spin-off of consciousness. All those people Vasilev refers to in this book - Kazhinskil,, Bekhterev, Setsenov, Leontovich, Lazarev and others - were hard-core natural scientists, as were the other Russian researchers of the first half of the century I have mentioned before, all of whom excelled in their own field yet felt that they needed to pronounce their views on matters spiritual, going beyond physics without falling into the trap of metaphysics. And they may have been motivated by personal reasons as well: by embracing the "religion of man", they may have sought to avoid the communist religion, or at least to find a way out of it. And, strange though it may seem to us today, they may even have succeeded, as most of these people managed to survive the decades of the Great Terror, and not only physically: they also managed to preserve their intellectual and moral integrity. ${ }^{13}$

In his 1963 book Vasilev writes a lot about parapsychology and its scientific grounding. The publication of this book coincided with the golden era of Soviet "non-conventional research", the years from the early

\footnotetext{
11 This is detailed by Michael Hagemeister in an excellent article (Hagemeister, 1997, pp. 185-202).

12 Although this quotation figures in almost all Soviet and Russian books that discuss telepathy, it is in fact not verifiable, as it is quoted by Kazhinskin in his book mentioned above from a private letter dated 1923It was an era of stagnation not only in the political and economic sense: adsons as well: with the 'efore, all of whomways froms.

13 Bekhterev is a special case in several respects: he served as a reliable point of reference for generations after 1917, and it is not certain whether he died from a natural cause after diagnosing Stalin. Chizhevskiĭ spent eight years in exile, but he was allowed to continue his research for some of that time.
} 
1960 s to the 1980s, i.e. the period of "stagnation" as it was called then. There were some results, most probably, but only partial and fragmentary data were published about the research (Kernbach, 2016, pp. 35-57). It was an era of stagnation not only in the political and economic sense: this period of Soviet esotericism and parapsychology can be described as a sort of peculiar state-party and secret-service tabloid culture, without any real depth of thought or human drama. The main question in that period was how to send signals over a great distance from the human brain (i.e. telepathy), what the nature of energy emanating from the human body (bioenergy) was, and how to produce the signals and the energy from non-human resources. Laboratories were funded by the state and controlled by the state security services. In the first period - from 1917 to 1934 (the beginning of Stalin's "great terror") - technical electronic research was conducted in Moscow, whereas biological and brain research resided in Leningrad, with the two institutions being practically unaware of each other's results, which were handled by high-ranking state security officers. We will probably never know what the latter made of the results, and accordingly, these institutes were eliminated by the Stalinist state.

The greatest myth of the third period is the one about a plant called Radioson (radio dream), set up in the vicinity of Novosibirsk in 1973, which ran on accumulated bioenergy, and was supposedly capable of putting to sleep the whole population of a town occupying 100 square kilometres and lying 55 kilometres away from the plant. ${ }^{14} \mathrm{~A}$ number of accounts mention that, at the time, security services were always on the lookout for Siberian shamans and Central Asian healers, in order to teach their astral bodies to detect enemy bases from a distance. The KGB found this a cheaper solution than sending out agents, which was a much more complicated and risky venture. As soon as the US administration learnt about the new methods of Soviet intelligence, they started to finance the so-called Sungate

\footnotetext{
14 The sources of these stories and data - memoirs and articles without real scientific value, found on the internet - are for the most part dubious and unreliable, e.g. "General KGB o psi-oruzhii" (2015), refuted here: Politdrug, 2015. Another typical example is Tim Rifat's book, Remote Viewing (2004) that can be downloaded from dozens of sources: https://targetedindividualscanada. com/2012/01/19/tim-rifat/. In his book, Rifat gives an enormous number of data without references or with incomplete references. For him, everything hangs together, but his conclusions, often drawn from correct statements or data, are dubious. The story of Radioson is told by Olga Greig, an author who worked with a similar method in her book Clairvoyants and Magicians Employed by the Secret Services of the World, with no references either (Greig 2016, p. 267). In his book written in Russian, Kernbach refers to Greig's book when discussing the Radioson affair (Kernbakh, 2015, p. 117), which makes one doubt the credibility of the latter as well. While using these sources in my summary of Soviet parapsychology, I have tried to remain sceptical and ironical when discussing views and descriptions that are obviously phantasms. The most neutral and informative source I found is a brief timeline: http://ezolife.info/?p=6559.
} 
(initially Stargate) programme (the 2010 film The Men Who Stare at Goats, directed by Grant Heslov, is a parody of that programme), which involved training psi warriors. The intelligence services of both countries tried to squeeze as much money as possible from their respective governments for the continuation of their programmes, claiming that there was imminent danger involved. According to the 1977 CIA report quoted above, there were eleven such institutes of various size in the Soviet Union in that period, employing from 10 to 500 researchers, with a total budget of half a billion roubles ${ }^{15}$. In 2003, support for these institutes was discontinued under pressure from the Russian Academy of Sciences, and in 2004 the naturopaths of the Kremlin were dismissed (Kuzina, 2005).

As these occurrences could not be completely suppressed from the public, the state power applied doublespeak, as was their wont: "serious" experiments designed to develop psi warfare were controlled by the war department and classified (and foreign intelligence officers were misinformed about them); academic institutes were commissioned to conduct physiological-physical experiments, researchers published their articles outside the Soviet Union as well (Vasilev's books, for example, were published in the West ${ }^{16}$ ), they attended international conferences on parapsychology, initiated public debates in the press, sometimes announcing that telepathy had been solved, at other times denying that the phenomenon existed, but they were always in control of what information could be disclosed to the public.

\section{Averting Danger to Society}

To sum up what has been said so far, "psychotronic" research, rather inconsistent with the scientific materialism of the regime, was kept alive by the unique disposition of Russian natural science on the one hand, and the power aspirations of the Soviet state on the other. However, as I mentioned before, this was merely the surface: the story of alleged mysteries, unfulfilled scenarios and games of the secret services. The real drama was played out on a different plane, and that story is about failed lives, freedom and death in abundance. Occultism, the "whore" which tried to set up shop in scientific and philosophical discourses and to influence the creative aspirations

\footnotetext{
15 The related sources, as seen from today's perspective, are more speculative than fact-finding or documentary. For instance, Ostrander and Schroeder's book published in 1970 (Psychic Discoveries Behind the Iron Curtain; Ostrander \& Schroeder, 1970) and even its 1997 edition introduced by Uri Geller, despite its pioneering character is now read more as fiction than an analytical study. One of the most erudite (though still far from academic) visions on the issue is provided by Martin Ebon in his Psychic Warfare: Threat or Illusion (Ebon, 1983).

16 It was through the works of Vasilev that the English-speaking world was informed about the results of Russian academics, little known elsewhere in the world ("Vasiliev, Leonid", n.d.)
} 
of artists and natural scientists, plays a central role in this story as well. Here, however, occultism was not part of a project to be realized; it was merely a buzzword for the illusion of a freer life. If, as Harari claims, ideologies can be construed as religions, then one can say that esoteric communities and movements fell victim to the inquisition of the era, while their representatives were trying to prove that their ideas in fact corroborated the true religion of the state. In what follows, I will mention a few incidents which illustrate the mechanisms of state terror and the rear-guard actions of autonomous communities.

After the Bolshevik takeover in 1917, secret societies - esoteric and spiritist circles, freemasons and Rosicrucians, Knights Templar and Martinists - continued to operate in the big cities as if nothing had happened: their membership kept growing, their lodges kept functioning, they gave lectures, debated, and proliferated as before. In his excellent article, Konstantin Burmistrov provides an overview of the activities and beliefs of these communities (Burmistrov, 2012). The case of Boris Astromov, the well-known actor and a central figure of the esoteric scene in Leningrad, is emblematic, as it illustrates the dramatic clash between the spiritual mindset and the severe reality of the new power. He founded a new lodge in 1922 when he fell out with some of the Brothers (scientists and public figures) and started to build a new network called Russian Autonomous Freemasons with his colleagues from the theatre and other artists. It is hard to tell in hindsight what those few hundred or few thousand intellectuals were hoping for at the dawn of Soviet state power. They were most probably unaware of the import of the events and thought that the secret nature of the society would protect them from the state security services. Astromov even offered his services to the NKVD and recruited some of the Brothers as agents, as he was of the opinion that freemasonry should be channelled into Soviet state power (Nikitin, 2000, p. 19).

"The Soviet power has already borrowed the symbols of freemasons: the pentangle, the sickle and the hammer ... [and] the aims of communism are largely similar to the endeavours of Russian freemasons", he wrote, adding that the Comintern would have to be reformed after the model of freemasonry so it would not be a thorn in the eyes of Western powers, and so that it would be able to continue working efficiently ("Astromov (Kirichenko) Boris Viktorovich", n.d.). A noble idea, except that he wrote these lines in 1926 in a letter to Stalin when he was under preliminary arrest in the Lubianka with the other Brothers. As it happened, the leadership of the state security services had changed in the meantime, and the new staff were not satisfied with mere surveillance. Astromov was imprisoned for years, then exiled, and, after another wave of repression in 1940, kept in a labour camp until his death. 
Occultists who lived in Moscow also met their fate soon enough: in 1928, those who were related to occultist circles in any way were arrested almost to a man, even though they operated in deep secrecy. It is perhaps not surprising that, before they were arrested, one of the missions of these circles had been to contribute to the research of the Moscow Institute of Brain Research on telepathy and telekinesis (Nikitin, 2000, p. 19). By the end of the 1930s, none of the "secret societies" were in operation. According to Aleksandr Nikitin, a historian who thoroughly researched the history of these societies and published the records of the proceedings of the NKVD, by the beginning of the 1940s all those who were related to these societies had fallen victim to successive waves of terror. By 1938, the mystical anarchists of Moscow met the same fate. Living under the protection of the Kropotkin memorial house in Moscow, they fought against their own anarchist comrades, so when it eventually came to eliminating all of them, the NKVD didn't have much to do.

Mystical anarchism, that unique Russian occult-revolutionary hybrid, spread around and became popular - and even dominant for some time in the Kropotkin house - through the activities of an ideologist called Apollon Karelin. He believed that a new ethical code must be introduced in order for the social goals of anarchism to be realized. The road to this new ethical code led through self-knowledge ("building up the inner self"), as it became obvious that actual revolution had resulted in the most horrible instincts breaking loose rather than true liberation - as he put it. Again, the threads come together: on the basis of reports about the proceedings, Nikitin convincingly reconstructs the personal and ideological links between the Knights Templar (aka Order of the Light) and the anarchists. In September 1930, however, the knights were arrested: thirty people, intellectuals and students without exception, all confessed that they were fighting for the triumph of good - the light - over the forces of darkness, combining the scientific results of their times with ancient lore (Nikitin, 2000, p. 50). They were naïve, benevolent, committed people - we will probably never know how many of them returned to tell the tale.

\section{Control and Correction in the Period of Sedition}

Perhaps the most beautiful metaphors for the extremely complicated relationship between Soviet state power and occultism are to be found in Tarkovskiî's films. The healing of the boy with a stammer and the crossing of the border line in Ivan's Childhood (1962), as well as the return of the father in Mirror (1974), an allusion to the end of massive repression, or the telekinetic scene at the end of Stalker (1979) - these were all understood 
by viewers as allusions to the waking up of Russian society, especially intellectuals, and to their need for spirituality, for self-awareness, and for building up an "inner self". There are lots of reports about that period when "dissidents" and "opposition groups" appeared on the scene, as KGB data and most contemporary party resolutions are now public. The relatively soft terror of the Khrushchëv and Brezhnev eras did not threaten heretics with death: rather, warning/"prophylactic" measures were introduced in cases which were within the limits of tolerance, e.g. for the distribution of brochures inciting against the state (Kazmin \& Kazmina, 2015, p. 15). This period is fittingly called kramola (sedition) in recent Russian academic literature, and this word accurately describes the common characteristics of sporadic spontaneous protests at the time: i.e. an instinctive reaction to the contradiction between the official narratives of the regime and the miserable reality (Kazmin \& Kazmina, 2015; Kozlov \& Mironenko, 2005).

From the 1960s, foreign Russian-language media had a great role in spreading nonconformist ideologies, student and hippie movements, musical subcultures and fashions. After the invasion of Czechoslovakia in 1968, human rights groups appeared in major cities (Alekseeva, 1992; Kozlov \& Mironenko, 2005; Makarov, 2006). Thus, kramola was nurtured by various sources and triggered various reactions, especially from generations under thirty, and the state power employed the same "correction mechanisms" in each case: on the bench for those accused by the Soviet authorities, Zionists sat side by side with neo-Nazis, religious fanatics with leftists who reproached the regime for not being faithful to Leninist principles, moralist artists with liberal human rights groups, factory workers who revolted spontaneously with schizoid, rebellious adolescents. It is therefore quite strange that books and articles on the history of kramola do not mention groups and communities who returned or turned to esoteric traditions, yet in this period, kramola would be an appropriate interpretative framework for these communities.

This time, the wanton idea of occultism hooked up with spiritual renaissance, and became one of the quiet manifestations of revolt. This scene was discussed the most thoroughly by psychologist Vladislav Lebed'ko in his three volumes of interviews entitled The Chronicle of Russian Sannyasa (Chapters from the Life of Russian Mystics from the 1960s to 1990). Sannyasa originally means the highest state of consciousness in Hinduism. The word also denotes those who quit everyday life, renounce earthly vanities, and live the life of the spirit. The author uses this word for the loose network which came into existence at the end of the 1960s, and consisted of people who turned away from Soviet society - as terror was beginning to abate - and started to experiment with self-knowledge and self-building, each in their 
own fashion, with homespun methods, and with the help of whatever books were available at the time.

This network consisted of a few dozen people who started to read the books of mystics, theosophists and occultists, like Carlos Castaneda, Gurdjieff, Ouspensky, Rerikh ${ }^{17}$, and many of these people were released from the camps at that time. They met these spiritual leaders, then gathered a small group of followers, and travelled to remote parts of the country to meditate and to find their true selves in a parallel reality. The main actors of this mystical underground scene, according to Lebed'ko's description, were often deviant, mentally unstable, uneducated individuals who appeared at times in the position of the therapist, and at other times in that of the patient - the author of the book himself was a client before he became a psychologist. If one reads the interviews, or rather the literal transcriptions of the conversations, one does not find out whether they achieved anything at all. They suffered minor or major persecutions and forced psychiatric treatment, they were mostly broken by drugs and alcohol, but they kept preaching their truth that they had formulated in seclusion from the world, pieced together from fragmentary knowledge, relying mainly on their inner resources. The occultist movements from the beginning of the 20th century continued or revived in Sannyasa, but the spiritualists of the anomic period that came in the wake of the terror of Stalin's regime did not want to channel occult ideas into a project of social redemption, and neither did they establish organizations or institutions for themselves: reading mystical samizdat, doing yoga for self-enhancement, and drug-induced psychedelic experiences were merely symptoms of that slow waking up which was sensitively perceived by Tarkovskiǔ in his early films.

\section{Instead of a Conclusion: Socio-Political Boundaries Between the Rational and the Irrational Revisited}

The complete history of the relations between Soviet state power and occultism has yet to be written. Strangely enough, authors who discuss the esotericism of the "state" and those who discuss "private" esotericism do not even reflect on each other's findings. Yet apparently this wanton "small narrative" was present throughout the "great narrative", changing its colour and form from time to time, turning to the left, then to the right, offering captivity or freedom, livelihood or illusions to those who encountered it on their way. It was certainly alive, as it is alive now, perhaps in a way that was predicted by Umberto Eco in Foucault's Pendulum, or, to cite a Central-

17 On the import of ideas, books and travelling concepts from the East and from the West in this period, see Menzel, 2012b. 
Eastern European example, as the Hungarian writer Viktor Horváth imagined in his novel entitled The Small Crack: the transcendent has moved into cyberspace (the mystical analogy of which is Akasha), telepathy has been ousted by e-communication, psi warfare has given way to hacking and misinformation through the internet, secret societies have turned into closed groups on social media sites, and instead of recruiting followers, adepts now recruit new users for their apps.

However, it would be premature to bury the occult doctrine, filtered through state socialism, in the world of cables and servers: occultism keeps rearing its head in political irrationalism and the emerging politics of illiberalism. In February 2019 Vladislav Surkov, also known as "Putin's Rasputin", a postmodern - or rather, post-truth - spin doctor, published a manifesto entitled "Putin's Long State". Surkov explains that Western political analysts are at a loss when they have to understand the paranormal behaviour of Russian voters. They put it down to populism, Surkov continues, because they have no other word for such behaviour, yet they should understand that this behaviour is going to be the norm in more and more countries in the near future. The choice of the word paranormal is far from being accidental, and Surkov does not put it in inverted commas: this word goes beyond the irrational behaviour of voters, and leads us to the occult, to a mystical spiritual community (sobornost in Russian), one of the central ideological pillars of the "Russian idea".

What Surkov talks about is a phenomenon that is considered trivial nowadays, a phenomenon that is supported by the cognitive psychology of the 2000s, which was translated into the language of politics by George Lakoff: "Progressives have accepted an old view of reason, dating back to the Enlightenment, namely, that reason is conscious, literal, logical, universal, unemotional, disembodied, and serves self-interest. As the cognitive and brain sciences have been showing, this is a false view of reason. Oddly enough, this matters. It may sound like an academic issue, but this assumption about the nature of reason has stood in the way of an effective progressive defence and advancement of democracy" (Lakoff, 2008 , p. 2). And indeed, the consequences of this recognition transcend the framework of academic debates: although the Eurasianism of Alexander Dugin, an ideology that has gradually grown into that of Putin's illiberal state since the 1990s, is very eclectic, there is one common element in all of its ingredients: an irrationality that affects people's emotions, and which is able to contain any number of ideologies, from fundamentalist Orthodox belief through occultism to an Italian-style fascism. There are traces of his ideas in the ideology of parties like Ataka in Bulgaria, Syriza in Greece and Jobbik in Hungary. The main tenets of Dugin's "postmodern 
spiritualism"18 can also be detected in the main work of László Bogár, the chief theoretician of Hungarian illiberalism, the leading ideologue of the first Orbán government (Bogár, 2006).

By concluding my essay with these reflections, I do not mean to suggest that occultism, esotericism and the myriad of irrational ideologies stemming from them - from a mythic view of the nation to global conspiracy theories - are necessarily the hotbed or the result of illiberal political systems. They are, however, a concomitant of such systems, echoing in the rhetoric of political leaders, in campaigns built on irrational fear, and in the propagandistic elements of memory politics. The now defunct state socialism applied various strategies (depending on its needs and possibilities at a given moment) against various forms of occult/esoteric/irrational thinking, as the latter carried the possibility of uncontrollable freedom: at times, the state power tried to annihilate them, at other times, to integrate and exploit their results, and at other times again, they simply assigned the explanation of such phenomena to medical science and criminology. Today's authoritarian regimes, however, recognized the psychological power of this "magic" (to use Durkheim's classical term), and made it an integral part of their everyday communication, thereby rearranging the boundaries of values within society, reinterpreting the Enlightenment values of liberty, equality and fraternity, and controlling the "paranormal" behaviour of their adherents in a way that the creators of the Novosibirsk Radioson project could not even dream of.

\section{References}

Alekseeva, L. (1992). Istoriia inakomysliia v SSSR. Moskva: Vest'.

Alexander, J. B. (1980). The new mental battlefield: "Beam me up, Spock". Military Review, 60(12), 47-54.

Antonov, V. (2015, June 16). Ėkstrasensy na sluzhbe Kremlia. Sovershenno sekretno, 2015(21(350)). Retrieved from http://www.aferizm.ru/chydesa/knight_dark/ ch_khights_dark_8-15-Kreml.htm

Astromov (Kirichenko) Boris Viktorovich. (n.d.). Retrieved from http://www.hrono. ru/biograf/bio_a/astromov.html

Baibakov, N. K. (2011). Sorok let v pravitelstve. Arkhangel'sk: Mezhdunar. fond "Fond innovatsii im. Baíbakova".

Bekhterev, V. M. (1994). Kak proiskhodit tak nazyvaemoe otgadyvanie mysleŭ na podmostkakh teatra. In V. M. Bekhterev, Gipnoz, vnushenie, telepatiia (pp. 317-332). Moskva: Mysl’.

Bogár, L. (2006). Magyarország és a globalizáció. Budapest: Ozirisz Kiadó.

18 See the excellent and still valid analysis by Mark Sedgwick (2012). 
Burmistrov, K. (2012). The history of esotericism in Soviet Russia in the 1920s-1930s. In M. Hagemeister, B. Menzel, \& B. G. Rosenthal (Eds.), The New Age of Russia: Occult and esoteric dimensions (pp. 52-80). Munich: Sagner.

Chazov, E. (2014). Khorovod smerteй: Brezhnev, Andropov, Chernenko. Moskva: Algoritm.

Dostoevskiŭ, F. M. (1972-1990). Polnoe sobranie sochineniǔ: Vol. 22. Dnevnik pisatelia. Leningrad: AN SSSR, Nauka - Pushkinskiı̌ Dom.

Ebon, M. (1983). Psychic warfare: Threat or illusion. New York, NY: McGraw-Hill.

Freud, S. (1941). Gesammelte Werke: Vol. 17. Psychoanalyse und Telepathie. Frankfurt: Fischer Taschenbuch Verlag. (1st ed. 1921).

General KGB o psi-oruzhii. (2015). Retrieved from https://cont.ws/@romster/126500

Greig, O. (2016). Ekstrasensy i magi v spetssluzhbakh mira. Moskva: TD Algoritm.

Gutierrez, C. (2009). Plato's ghost: Spiritualism in the American Renaissance. Oxford: Oxford University Press. https://doi.org/10.1093/acprof:oso/9780195388350.001. 0001

Hagemeister, M. (1997). Russian cosmism in the 1920s and today. In B. G. Rosenthal (Ed.), The occult in Russian and Soviet culture (pp. 185-202). Ithaca, NY: Cornell University Press.

Hamilton, T. (1977). Soviet and East European parapsychology research. Central Intelligence Agency. Retrieved from https:/www.cia.gov/library/readingroom/ docs/NSA-RDP96X00790R000100010041-2.pdf

Harari, Y. N. (2014). Sapiens: A brief history of humankind. Toronto: Signal Books, McClelland \& Stewart.

Kazhinskiŭ, B. (1923). Peredacha mysleŭ. Moskva: Vserossiǔskă̌a Assotsiatsiia Naturalistov. Retrieved from https://www.litmir.me/br/?b=559936\&p=1

Kazhinskiǔ, B. (1963). Biologicheskaia radiosviaz'. Kiev: Izdatel'stvo akademii nauk Ukrainskoŭ SSR.

Kazmin, M. V., \& Kazmina, M. B. (2015). Formy protestnoŭ deiatel'nosti v Rossii v 60-80-e gg. XX veka. Vestnik Kemerovskogo gosudarstvenogo universiteta, 2015(4(64)), 14-17.

Kernbach, S. (2016). Unconventional research in USSR and Russia: Short overview. International Journal of Unconventional Science, 2016(E1), 35-57.

Kernbakh, S. (2015). Sverkh"estestvennoe: Nauchno dokazannye fakty. Moskva: Algoritm.

Kozlov, V., \& Mironenko, S. (Eds.).(2005). Kramola: Inakomysliev SSSR pri Khrushcheve i Brezhneve, 1953-1982 gg: Rassekrechennye dokumenty Verkhovnogo suda i Prokuratury SSSR. Moskva: Materik.

Kuzina, S. (2005, January 5). Kremlëvskikh èkstrasensov otpravili v otstavku. Komsomol'skaia pravda.

Lakoff, G. (2008). The political mind: A cognitive scientist's guide to your brain and its politics. London: Penguin Books.

Lebed'ko, V. (1999). Khroniki rossiǔskoŭ San'iasy. Moskva: Tema. 
Leont'ev, A. N., Lomov, B. F., Zinchenko, V. P., \& Luriia, A. R. (1973). Parapsikhologiia: Fiktsiia ili real'nost'? Voprosy filosofii, 1973(3), 128-136.

Leont'ev, A. N., Lomov, B. F., Zinchenko, V. P., \& Luriia, A. R. (1979) Parapsychology: fiction or fact. In S. Krippner (Ed.), Psychoenergetic systems (pp. 255-262). New York, NY: Gordon \& Breach.

Maire, L. F., \& LaMothe, J. D. (2014). Soviet and Czechoslovakian parapsychology research: The DIA Report from 1975 with new addenda. Retrieved from https:// www.cia.gov/library/readingroom/docs/CIA-RDP96-00792R000600350001-3. pdf

Makarov, A. (Ed.). (2006). Vlast' i dissidenty: Iz dok. KGB i TSK KPSS. Moskva: Moskovskaia Hel'sinskaia Gruppa.

May, E. C., \& Rubel, V. (Eds.). (2014). ESP Wars: East and West: An account of the military use of psychic espionage as narrated by the key Russian and American players. Palo Alto, CA: Laboratories for Fundamental Research.

Mendeleev, D. (1876). Dva publichnykh chteniia o spiritizme. In Materialy dlia suzhdeniia o spiritizme (pp. 321-382). Sankt-Peterburg: Author's edition. Retrieved from http://alkruglov.narod.ru/mendspir.html

Menzel, B. (2012a). Introduction. In M. Hagemeister, B. Menzel, \& B. G. Rosenthal (Eds.), The New Age of Russia: Occult and esoteric dimensions. Munich: Sagner.

Menzel, B. (2012b). Occult and esoteric movements in Russia from the 1960s to the 1980s. In M. Hagemeister, B. Menzel, \& B. G. Rosenthal (Eds.), The New Age of Russia: Occult and esoteric dimensions (pp. 151-185). Munich: Sagner.

Menzel, B. (2016). Parapsychologie im sowjetischen und postsowjetischen Raum: Status, Forschung, Experimente. In A. Lux \& S. Paletschek (Eds.), Okkultismus im Gehäuse: Institutionalisierungen der Parapsychologie $m$ 20. Jahrhundert im Internationalen Vergleich (pp. 149-172). München: De Gruyter/Oldenbourg.

Moiseeva, O. (2018, June 13). Astrologi, èkstrasensy i drugie taŭnye sovetniki sovetskikh vozhdel. Ekspress gazeta. Retrieved from https:/www.eg.ru/politics/548576/

Nikitin, A. (2000). Mistiki, rozenkreitsery i tampliery v Sovetskoŭ Rossii. Moskva: Agraf.

Osterrieder, M. (2012). From synarchy to Shambhala: The role of political occultism and social messianism in the activities of Nicholas Roerich. In M. Hagemeister, B. Menzel, \& B. G. Rosenthal (Eds.), The New Age of Russia: Occult and esoteric dimensions (pp. 101-134). Munich: Sagner.

Ostrander, S., \& Schroeder, L. (1970). Psychic discoveries behind the Iron Curtain. New York, NY: Bantam Books.

Parapsikhologiia: Znachenie slova "Parapsikhologiia" v Bol'shoŭ Sovetskoŭ Éntsiklopedii. (n.d.). Retrieved from http://bse.sci-lib.com/article086932.html

Perevozchikov, A. (1988). Delo o telekineze. Tekhnika Molodëzhi, 1988(5-7), 46-50. Retrieved from http://www.forumknig.ru/index/18_36_95/

Politdrug, E. (2015, December 10). Ėkstrasensy na sluzhbe KGB: Istoriia sovetskogo bezumiia. Sputnik i Pogrom. Retrieved from https://sputnikipogrom.com/ russia/47872/kgb-lunatics/

Rifat, T. (2004). Remote viewing and sensing for managers. London: Vision 
Rosenthal, B. G. (1997). Introduction. In B. G. Rosenthal (Ed.), The occult in Russian and Soviet culture (pp. 1-32). Ithaca, NY: Cornell University Press.

Rubel', V. A. (Ed.). (2013). PSI-voinn: Zapad i Vostok: Istoriia voennogo primeneniia èkstrasensoriki. Moskva: Postum.

Sedgwick, M. (2012). Occult dissident culture: The case of Aleksandr Dugin. In M. Hagemeister, B. Menzel, \& B. G. Rosenthal (Eds.), The New Age of Russia: Occult and esoteric dimensions. Munich: Sagner. 273-292

Shingarov, G. (1994). O V. M. Bekhtereve - vrache-gipnologe. In V. M. Bekhterev, Gipnoz, vnushenie, telepatiia (pp. 5-45). Moskva: Mysl'.

Surkov, V. (2019, February 11). Dolgoe gosudarstvo Putina. Nezavisimaia gazeta. Retrieved from http://www.ng.ru/ideas/2019-02-11/5_7503_surkov.html

Vasil'ev, L. L. (1962). Vnushenie na rasstoianii: Zametki fiziologa. Moskva: Gospolizdat. Vasiliev, Leonid. (n.d.). Retrieved from https://allaboutheaven.org/sources/ vasiliev-leonid/190

Vinitsky, I. (2008). Ghostly paradoxes: Modern spiritualism and Russian culture in the age of realism. Toronto: University of Toronto Press. https://doi. org/10.3138/9781442697959

\section{Az ideológiák szürkületében: hatalom és ezoterika a szovjet állami szocializmusban}

A 19-20. század fordulóján Oroszország szellemi, tudományos és művészi életében az ezoterikus/okkult eszmék és mozgalmak meghatározó szerepet játszottak. Az okkultizmus szinte minden 19. századi ideológiával képes volt valamiféle szimbiózisba kerülni, s ezt a különös tulajdonságát a hivatalosan ellenséges államszocialista ideológiai közegbe is képes volt bizonyos mértékig átörökíteni. A „dialektikus materializmus” alapjain álló hatalom viszonya az okkult eszmék továbbélési formáihoz ugyanakkor nem mindig volt egyértelmü: ez korszakonként és az eszmék társadalmi-közösségei hatásától függően is változott. A tanulmány értelmezési kereteket próbál javasolni az ezotéria és szovjethatalom sajátosan bizarr dinamikájú viszonyára, s arra a következtetésre jut, hogy az ezoterikus eszmék különböző megnyilvánulási formái - a (kvázi)tudományos, a közösségépítő és az individuális-önmegvalósító - által kiváltott hatalmi reakció más-más interpretációs megközelítést igényel.

Kulcsszavak: Szovjet tudomány, ezoterikus mozgalmak, parapszichológia, okkultizmus, természetfeletti jelenségek, ellenállás, titkosszolgálatok. 


\section{W mroku ideologii: władza i ezoteryka w radzieckim socjalizmie państwowym}

Na przełomie XIX i XX wieku idee i ruchy ezoteryczne/okultystyczne grały znaczącą rolę w życiu duchowym, naukowym i artystycznym Rosji. Okultyzm był w stanie wejść $\mathrm{w}$ jakiś rodzaj symbiozy z niemal każdą dziewiętnastowieczną ideologią i do pewnego stopnia mógł przekazać w spadku tę szczególną sposobność oficjalnie wrogim im ideologicznie organom państwa socjalistycznego. Jednak relacja między władzą państwową, opartą na „materializmie dialektycznym”, a różnymi formami okultystycznych idei, które przetrwały w tamtym okresie, nie zawsze była jasna: zawsze zmieniała się ona wraz z upływem czasu i zależała od wpływu tych idei na społeczeństwo.

Niniejszy artykuł proponuje pewne ramy interpretacji niecodziennej dynamiki relacji stosunków między ezoteryzmem i władzą radziecką, oraz dochodzi do konkluzji, że ogromna reakcja [władzy państwowej] wywołana poprzez różne formy manifestacji idei ezoterycznych - quasi-naukowe, tworzące wspólnotę, indywidualnie się realizujące - wymaga wielu różnych podejść interpretacyjnych.

Słowa kluczowe: sowietologia, ruchy ezoteryczne, parapsychologia, okultyzm, zjawiska paranormalne, opór, tajne służby.

Przełożyła z języka węgierskiego

Adrianna Janas

\section{Note}

Péter Krasztev, Department of Social Communication, Budapest Business School, Budapest.

krasztev@gmail.com

The preparation of the article was self-funded by the author.

No competing interests have been declared. 